\title{
PENEGAKAN HUKUM TERHADAP JAKSA YANG MELAKUKAN TINDAK PIDANA NARKOTIKA
}

\author{
Suwari Akhmaddhian, Wisnu Gita Prapanca \\ Fakultas Hukum, Universitas Kuningan, Indonesia \\ Email : wisnuprapanca@gmail.com
}

\begin{abstract}
The purpose of this study is to find out how is the code of conduct for prosecutors in Indonesia? settlement of cases of violation of the Code of Ethics of the Prosecutor conducting Narcotics distribution? The research method used is normative juridical, which is an approach method by studying the law which is conceptualized as a norm or rule that applies in society, and serves as a reference for everyone's behavior. data collection tool through library research. ata used secondary, that is data obtained through the study of documentation by reading scientific books, magazines, internet, newspapers and other readings related to research. The results of the study are the setting of a prosecutor's code of ethics contained in Law Number 16 of 2004 concerning the Attorney General's Office of the Republic of Indonesia and Regulation of the Attorney General of the Republic of Indonesia number: PER-o67 / A / JA / o7/2007 concerning the Attorney Code of Ethics. Completion of cases of violations of the Code of Ethics for Prosecutors who commit violations of ethical conduct, namely examinations by the prosecuting supervisor and the type of severe punishment may be imposed on prosecutors in the form of dismissal with respect or vice versa with respect. In addition, the release from functional or structural positions.
\end{abstract}

Keywords: sanctions; code of Ethics; prosecutor; case; judicial mafia.

Abstrak

Tujuan penelitian ini adalah untuk mengetahui bagaimana bagaimana pengaturan kode etik bagi Jaksa di Indonesia? penyelesaian kasus pelanggaran Kode Etik Jaksa yang melakukan pengedaran Narkotika? Metode penelitian yang digunakan adalah yuridis normatif, yaitu metode pendekatan dengan mengkaji hukum yang dikonsepkan sebagai norma atau kaidah yang berlaku dalam masyarakat, dan menjadi acuan perilaku setiap orang. alat pengumpul data melalui studi kepustakaan. ata yang digunakan sekunder, yaitu data yang diperoleh melalui studi dokumentasi dengan cara membaca buku-buku ilmiah, majalah, internet, surat kabar dan bacaan-bacaan lain yang berhubungan dengan penelitian. Hasil penelitian yaitu pengaturan kode etik jaksa terdapat dalam Undang-Undang Nomor 16 Tahun 2004 tentang Kejaksan Republik Indonesia dan Peraturan Jaksa Agung Republik Indonesia nomor : PER-067/A/JA/07/2007 tentang Kode Etik Jaksa. Penyelesaian kasus pelanggaran Kode Etik Jaksa yang melakukan pelanggaran kose etik yaitu pemeriksaan oleh jaksa pengawas dan jenis hukuman berat dapat dikenakan terhadap jaksa berupa pemberhentian dengan tidak hormat atau sebaliknya dengan hormat. Selain itu pembebasan dari jabatan fungsional ataupun struktural.

Kata Kunci : sanksi; kode etik; jaksa; perkara; mafia peradilan.

\section{PENDAHULUAN}

Kejaksaan sebagai lembaga penegak hukum melaksanakan tugasnya secara merdeka dengan menjujung tinggi hak asasi manusia dalam negara hukum berdasarkan Pancasila dan Undang Undang Dasar Negara Republik Indonesia Tahun 1945 serta diatur secara khusus dalam Undang-Undang Nomor 16 Tahun 2004 tentang Kejaksan Republik Indonesia. Sebagai lembaga pemerintahan yang melaksanakan kekuasaan negara di bidang penuntutan serta tugas-tugas lain berdasarkan peraturan perundang-undangan, Kejaksaan memerlukan adanya satu tata pikir, tata laku dan tata kerja Jaksa dengan mengingat norma-norma agama, susila, kesopanan serta memperhatikan rasa keadilan dan nilai-nilai kemanusiaan dalam masyarakat. Dalam melaksanakan tugas dan wewenangnya, diperlukan sosok Jaksa sebagai abdi hukum yang profesional, memiliki integritas kepribadian, disiplin, etos kerja 
Logika : Journal of Multidisciplinary Studies, ISSN 2085-9970.

Vol. 10 Nomor 01 Juni 2019. 60-68.

yang tinggi dan penuh tanggung jawab, senantiasa mengaktualisasikan diri dengan memahami perkembangan global, tanggap dan mampu menyesuaikan diri dalam rangka memelihara citra profesi dan kinerja jaksa serta tidak bermental korup ${ }^{1}$. Jaksa sebagai pejabat publik senantiasa menunjukkan pengabdiannya melayani public dengan mengutamakan kepentingan umum, mentaati sumpah jabatan, menjunjung tinggi doktrin Tri Krama Adhyaksa, serta membina hubungan kerjasama dengan pejabat publik lainnya. Jaksa sebagai anggota masyarakat selalu menunjukkan keteladanan yang baik, bersikap dan berperilaku sesuai dengan nilai-nilai yang hidup dan berkembang serta peraturan perundang- undangan.

Secara normatif (das solen) tugas dan kewajiban kejaksaan dapat dikatakan hal yang sempurna mencakup hal yang cukup luas. Kejaksaan atau khususnya jaksa mempunyai kedudukan sebagai wakil Negara dalam bidang peradilan. Akan sangat maju dan baik peradilan di Indonesia jika tugas dan kewajiban dari lembaga kejaksaan itu dilaksanakan dengan baik, dalam artian tetap menjaga idealisme lembaga kejaksaan sebagai penegak keadilan walaupun berhadapan dengan realita kehidupan. Mafia peradilan, itulah istilah yang kini cukup popular dibicarakan di masyarakat. Bagaimana tidak, lembaga kejaksaan yang harusnya menegakkan hukum justru menggunakan hukum sebagai lahan usaha. Nilainilai keluhuran hukum tidak lagi dijunjung tinggi. Dalam menangani suatu kasus di peradilan tidak jarang aparat penegak hukum dalam hal ini hakim, jaksa, dan penasihat hokum "main mata." Hukum pun dipermainkan untuk kepentingan mereka sendiri. ${ }^{2}$

Pengertian Jaksa adalah pejabat fungsional yang diberi wewenang oleh undangundang untuk bertindak sebagai penuntut umum dan pelaksanaan putusan pengadilan yang telah memperoleh kekuatan hukum tetap serta wewenang lain berdasarkan undangundang ${ }^{3}$. Jabatan fungsional jaksa adalah jabatan yang bersifat keahlian teknis dalam organisasi kejaksaan yang karena fungsinya memungkinkan kelancaran pelaksanaan tugas kejaksaan. Jaksa diangkat dan diberhentikan oleh Jaksa Agung yang merupakan pimpinan dan penanggung jawab tertinggi kejaksaan yang dipimpin, mengendalikan pelaksanaan tugas dan wewenang kejaksaan.

Pengertian Jaksa Agung adalah pejabat negera yang diangkat dan diberhentikan oleh Presiden dengan persyaratan tertentu berdasarkan undang-undang. Oleh karena Jaksa Agung diangkat oleh Presiden maka dalam menjalankan tugasnya Jaksa Agung adalah menjalankan tugas negara, karena Presiden mengangkat Jaksa Agung kedudukannya sebagai kepala negara (kekuasaan federatif) dan bukan sebagai kepala pemerintahan (kekuasaan eksekutif). Demikian juga jaksa yang diangkat oleh Jaksa Agung dalam menjalankan tugasnya adalah menjalankan tugas negara dan bukan tugas pemerintahan. Jaksa dalam menjalankan tugas dan fungsinya harus selalu perpegang teguh pada kode etik yang dalam hal ini adalah Peraturan Jaksa Agung Republik Indonesia Nomor : PER-o67/A/ JA/o7/2007, tentang Kode Etik Perilaku Jaksa. Adapun rumusan masalah yang digunakan dalam artikel

\footnotetext{
${ }^{1}$ Liliana Tedjosaputro, dalam Supriadi tentang Etika \& Tanggung Jawab Profesi Hukum Di Indonesia,Sinar Grafika, Jakarta, 2006,hlm. 132

${ }^{2}$ Sukarton Marmosudjono, Melihat Nilai Etika dari segi Keluhuran Hukum, jakarta, 1998

3 Soerjono Soekanto, tentang pengertian Jaksa,Jaksa Agung, Jakarta, 2009,hlm. 12
} 
Logika : Journal of Multidisciplinary Studies, ISSN 2085-9970.

Vol. 10 Nomor 01 Juni 2019. 60-68.

ini adalah bagaimana pengaturan kode etik bagi Jaksa di Indonesia? Bagaimana Penyelesaian Kasus Pelanggaran Kode Etik Jaksa yang melakukan pengedaran Narkotika?

\section{METODE PENELITIAN}

Metode penelitian yang digunakan oleh penulis adalah Yuridis Normatif, dengan alat pengumpul data melalui studi kepustakaan yaitu studi dokumentasi peraturan perundangundangan serta artikel-artikel yang terkait dengan penelitian ini.

\section{HASIL DAN PEMBAHASAN}

\section{A. Pengaturan Kode Etik untuk Jaksa di Indonesia}

Kata etika, sering disebut pula dengan istilah etik, atau ethics (bahasa Inggris), mengandung banyak pengertian. Dari segi etimologi (asal kata), istilah etika berasal dari kata Latin "ethicus" dan dalam bahasa Yunani disebut "ethicos" yang berarti kebiasaan. Dengan demikian menurut pengertian yang asli, yang dikatakan baik itu apabila sesuai dengan kebiasaan masyarakat. Kemudian lambat laun pengertian ini berubah, bahwa etika adalah suatu ilmu yang membicarakan masalah perbuatan atau tingkah laku manusia, mana yang dapat dinilai baik dan mana yang dapat dinilai tidak baik. ${ }^{4}$

Jabatan fungsional jaksa adalah bersifat keahlian teknis yang melakukan penuntutan. Bahwa dalam rangka mewujudkan jaksa yang memiliki integritas kepribadian serta disiplin tinggi guna melaksanakan tugas penegakan hukum dalam mewujudkan keadilan dan kebenaran, maka diperlukan adanya kode etik profesi jaksa. Kode etik profesi jaksa diatur dalam peraturan Jaksa Agung Republik Indonesia Nomor : PER-o67/A/ JA/o7/2007, tentang Kode Etik Perilaku Jaksa. Pada prinsipnya dalam melaksanakan tugas profesi, jaksa wajib :

1. Menaati kaidah hukum, peraturan perundang-undangan, dan peraturan kedinasan yang berlaku.

2. Menghormati prinsip cepat, sederhana, biaya ringan sesuai dengan prosedur yang ditetapkan.

3. Mendasarkan pada keyakinan dan alat bukti yang sah untuk mencapai keadilan dan kebenaran.

4. Bersikap mandiri, bebas dari pengaruh, tekanan atau ancaman opini publik secara langsung atau tidak langsung.

5. Bertindak secara objektif dan tidak memihak.

6. Memberitahukan dan/atau memberikan hak-hak yang dimiliki oleh tersangka atau terdakwa maupun korban.

7. Membangun dan memelihara hubungan fungsional antara aparat penegak hukum dalam mewujudkan sistem peradilan pidana terpadu.

8. Mengundurkan diri dari penanganan perkara yang mempunyai kepentingan pribadi atau keluarga, mempunyai hubungan pekerjaan, partai atau finansial atau mempunyai nilai ekonomis secara langsung atau tidak langsung.

9. Menyimpan dan memegang rahasia sesuatu yang seharusnya dirahasiakan.

10. Menghormati kebebasan dan perbedaan pendapat sepanjang tidak melanggar ketentuan peraturan perundang-undangan.

4 Harian Orbith,Pengertian Etika dalam artian luas , Jakarta, 2009,hlm. 32 
Logika : Journal of Multidisciplinary Studies, ISSN 2085-9970.

Vol. 10 Nomor 01 Juni 2019. 60-68.

11. Menghormati dan melindungi hak asasi manusia dan hak-hak kebebasan sebagaimana yang tertera dalam peraturan perundang-undangan dan instrumen hak asasi manusia yang diterima secara universal.

12. Menanggapi kritik dengan arif dan bijaksana.

13. Bertanggung jawab secara internal dan berjenjang, sesuai dengan prosedur yang ditetapkan.

14. Bertanggung jawab secara eksternal kepada publik sesuai kebijakan pemerintah dan aspirasi masyarakat tentang keadilan dan kebenaran.

Sehingga dalam mewujudkan sebuah pelayanan publik yang prima, seorang pegawai negri sipil harus mematuhi segala kode etik pegawai negri yang telah diatur tersebut sebagai tanggung jawab pegawai negri sipil. Sebagai bentuk apresiasi dari pemerintah atas kinerja dari pegawai negri sipil tersebut terdapat reward (penghargaan). Sedangkan, apabila terdapat pegawai negri sipil yang melakukan pelanggaran terhadap peraturan yang telah di buat tersebut akan dikenai punishment (sanksi). Kode etik adalah merupakan suatu bentuk aturan tertulis yang secara sistematik sengaja dibuat berdasarkan prinsip-prinsip moral yang ada dan pada saat yang dibutuhkan akan dapat difungsikan sebagai alat untuk menghakimi segala macam tindakan yang secara logika-rasional umum (common sense) dinilai menyimpang dari kode etik. Dengan demikian kode etik adalah refleksi dari apa yang disebut dengan "self control", karena segala sesuatunya dibuat dan diterapkan dari dan untuk kepentingan kelompok sosial (profesi) itu sendiri.

Kode etik untuk sebuah profesi adalah sumpah jabatan yang juga diucapkan oleh para pejabat Negara. Kode etik dan sumpah adalah janji yang harus dipegang teguh. Artinya, tidak ada toleransi terhadap siapa pun yang melanggarnya. Benar adanya, dibutuhkan sanksi keras terhadap pelanggar sumpah dan kode etik profesi. Bahkan, apabila memenuhi unsur adanya tindakan pidana atau perdata, selayaknya para pelanggar sumpah dan kode etik itu harus diseret ke pengadilan.Kita memang harus memiliki keberanian untuk lebih bersikap tegas terhadap penyalahgunaan profesi di bidang apa pun. Kita pun tidak boleh bersikap diskrimatif dan tebang pilih dalam menegakkan hukum di Indonesia. Kode etik dan sumpah jabatan harus ditegakkan dengan sungguh-sungguh. Profesi apa pun sesungguhnya tidak memiliki kekebalan di bidang hukum. Penyalahgunaan profesi dengan berlindung di balik kode etik profesi harus diberantas. Kita harus mengakhiri praktik-praktik curang dan penuh manipulatif dari sebagian elite masyarakat. Ini penting dilakukan, kalau Indonesia ingin menjadi sebuah Negara dan Bangsa yang bermartabat. ${ }^{5}$ Kode etik profesi itu merupakan sarana untuk membantu para pelaksana sebagai seseorang yang professional supaya tidak dapat merusak etika profesi. Ada tiga hal pokok yang merupakan fungsi dari kode etik profesi:

1. Kode etik profesi memberikan pedoman bagi setiap anggota profesi tentang prinsip profesionalitas yang digariskan. Maksudnya bahwa dengan kode etik profesi, pelaksana profesi mampu mengetahui suatu hal yang boleh dilakukan dan yang tidak boleh dilakukan.

5 M. Yahya Harahap, Kode Etik sebagai pelaksana para profesionaletika profesi,Jakarta, 1998 
2. Kode etik profesi merupakan sarana kontrol sosial bagi masyarakat atas profesi yang bersangkutan. Maksudnya bahwa etika profesi dapat memberikan suatu pengetahuan kepada masyarakat agar juga dapat memahami arti pentingnya suatu profesi, sehingga memungkinkan pengontrolan terhadap para pelaksana di lapangan kerja (kalangan sosial).

3. Kode etik profesi mencegah campur tangan pihak di luar organisasi profesi tentang hubungan etika dalam keanggotaan profesi. Arti tersebut dapat dijelaskan bahwa para pelaksana profesi pada suatu instansi atau perusahaan yang lain tidak boleh mencampuri pelaksanaan profesi di lain instansi atau perusahaan.

Jaksa mempunyai kewajiban yang harus dilaksanakan sesuai dengan ketentuan di atas, dalam melaksanakan tugas profesi, Jaksa dilarang ${ }^{6}$ :

1. Menggunakan jabatan dan/atau kekuasaannya untuk kepentingan pribadi dan/atau pihak lain.

2. Merekayasa fakta-fakta hukum dalam penanganan perkara. Dalam menentukan dasar hukum yang akan dikenakan kepada tersangka atau terdakwa dalam proses penangan perkara harus sesuai dengan fakta yuridis yang ada dan tidak boleh melakukan manipulasi atau memutar balikkan fakta yang berakibat melemahkan atau meniadakan ketentuan pidana yang seharusnya didakwakan dan dibuktikan.

3. Menggunakan kapasitas dan otoritasnya untuk melakukan penekanan secara fisik dan/atau psikis. Larangan untuk melakukan penekanan dengan cara mengancam/ manakut-nakuti guna memperoleh keuntungan pribadi atau pihak lainnya.

4. Meminta dan/atau menerima hadiah dan/atau keuntungan serta melarang keluarganya meminta dan/atau menerima hadiah dan/atau keuntungan sehubungan dengan jabatannya. Upaya untuk meminta dan/atau menerima walaupun tidak ada tindak lanjutnya berupa pemberian atau hadiah merupakan pelanggaran menurut ayat ini. Larangan untuk meminta dan/atau menerima hadiah dan/atau keuntungan termasuk bagi keluarga, pada atau dari pihak tertentu dimaksudkan untuk menghindari adanya maksud-maksud tertentu sehingga dapat memengaruhi jaksa dalam melaksanakan tugas profesinya. Selain itu, juga dimaksudkan untuk menjaga integritas jaksa.

5. Menangani perkara yang mempunyai kepentingan pribadi atau keluarga, mempunyai hubungan pekerjaan, partai atau finansial atau mempunyai nilai ekonomis secara langsung atau tidak langsung. Seorang jaksa tidak boleh menangani suatu perkara di mana jaksa tersebut memiliki hubungan keluarga, hubungan suami istri meskipun telah bercerai, hubungan pertemanan dan hubungan pekerjaan di luar menjalankan jabatan sebagai jaksa dengan pihak yang sedang diproses, serta kepentingan finansial yang dapat memengaruhi jalannya proses hukum yang sedang ditangani oleh jaksa tersebut.

6. Bertindak diskriminatif dalam bentuk apa pun. Jaksa dengan alasan apa pun tidak dibenarkan melakukan pembedaan perlakuan terhadap seseorang berdasarkan agama, suku, ras, etnik, kelompok, golongan, status sosial, status ekonomi, jenis kelamin,

${ }^{6}$ Dr. Sidharta, SH.,MH., Moralitas PROFESI HUKUM, Bandung : PT Refika Aditama, 2006. 
bahasa, keyakinan politik, yang berakibat pengurangan, penyimpangan atau penghapusan pengakuan atau pelanggaran hak hukumnya.

7. Membentuk opini publik yang dapat merugikan kepentingan penegakan hukum. Dalam melaksanakan tugas sebagai jaksa semata-mata dalam rangka menegakkan hukum dan keadilan, terdapat hal yang tidak perlu diketahui oleh publik karena dapat berpengaruh pada proses penegakan hukum, untuk itu jaksa tidak diperbolehkan membuat pernyataan yang dapat merugikan penegakan hukum kepada publik.

8. Memberikan keterangan kepada publik kecuali terbatas pada hal-hal teknis perkara yang ditangani.

Jaksa sering kali didiskreditkan melalui komentar dari berbagai pihak dalam berbagai media secara tidak objektif, tidak akurat atau kurang informasi, dan cenderung merugikan kejaksaan, jaksa tersebut sesuai dengan kondisi yang ada dapat memberikan keterangan hanya terbatas pada teknis perkara yang ditangani pada tahap persidangan di pengadilan agar terdapat informasi yang berimbang yang diterima oleh masyarakat. Keterangan yang disampaikan tidak boleh menyangkut, informasi yang dapat merugikan penanganan perkara. Selain itu, keterangan tidak boleh menyangkut perkara-perkara yang lain yang tidak relevan dengan perkara yang ditangani. ${ }^{7}$

\section{B. Penyelesaian Kasus Pelanggaran Kode Etik Jaksa \\ 1. Kronologi Perkara yang melibatkan Jaksa}

Umriani, seorang jaksa di Sumatera Utara terancam dipecat lantaran diduga menjadi makelar kasus dalam perkara narkotika jenis sabu-sabu. Demikian diungkapkan Jaksa Agung Muda Pengawasan (Jamwas) Marwan Effendi. "Kalau terbukti pasti hukumannya berat," ujar Marwan kepada wartawan, Kamis (19/8).

Kabar tentang jaksa Umriani memang santer di beberapa media. Pasalnya Kepala Kejaksaan Tinggi (Kajati) Sumatera Utara mengajukan pencopotan jaksa Umriani kepada Kejaksaan Agung. Lebih jauh marwan menjelaskan pihaknya belum menerima hasil pemeriksaan terhadap jaksa Umriani yang dilakukan oleh bidang pengawasan Kejati Sumut. Marwan yang mantan Jampidsus ini menjelaskan jenis hukuman berat dapat dikenakan terhadap jaksa Umriani berupa pemberhentian dengan tidak hormat atau sebaliknya dengan hormat. Selain itu pembebasan dari jabatan fungsional ataupun struktural. "Saya masih menunggu laporan dari Kajati Sumut. Penurunan pangkat itu tergantung dari kadar kesalahannya yang terbukti nanti," tuturnya.

Terpisah, Kepala Pusat Penerangan Hukum (Kapuspenkum) Kejagung, Babul Khoir Harahap menegaskan bahwa jaksa Umriani sejak lama tak pernah diberi amanah untuk menangani perkara. Pasalnya itu tadi, jaksa Umriani dapat 'bermain' dengan perkara yang dia tangani. Dijelaskan mantan Wakil Kepala Kejaksaan Tinggi (Wakajati) Sumut ini jaksa Umriani saat ini berstatus fungsional di intelijen Kejati Sumut. "Dia memang jarang dikasih perkara, karena kita was-was," ujarnya.

Perlu diketahui, terbongkarnya ulah jaksa Umriani lantara keluarga Angling Yusuf yakni terdakwa dalam kasus narkoba lantaran tidak menerima hasil putusan sebagaimana yang dijanjikannya. Keluarga Angling mengaku telah memberikan uang Rp318 juta kepada

7 Agus Santoso, 2014. Hukum, Moral, Dan Keadilan. Yang Menerbitkan Kencana Prenada Media Group : Jakarta 
jaksa Umriani dengan imbalan hukumannya di bawah 10 tahun. Namun, pengadilan setempat mempunyai pandangan berbeda. Alhasil, putusan pengadilan terhadap Angling malah 10 tahun penjara. Nah, tak terima atas putusan tersebut, pihak keluarga Angling meminta kembali uang yang telah diberikan kepada jaksa Umriani. Namun, uang yang dikembalikan hanya Rp15o juta. Sementara sisanya sebesar Rp168 juta tak juga diterima keluarga Angling. Pada tahun 2011, Jaksa Umriani telah dicopot jabatannya oleh kejaksaan agung. Jaksa umriani terbukti menjadi makelar kasus narkoba terhadap keluarga Angling Yusuf. Dengan keputusan itu, jelasnya, Jaksa Umriani tidak bisa lagi mengikuti kegiatan penyidikan dan penuntutan.

\section{Analisis Kasus yang melibatkan Jaksa}

Kode etik profesi merupakan norma yang ditetapkan dan diterima oleh kelompok profesi, yang mengarahkan atau member petunjuk kepada anggotanya bagaimana seharusnya berbuat dan sekaligus menjamin mutu moral profesi itu dimata masyarakat. Apalagi satu anggota kelompok profesi itu berbuat menyimpang dari kode etiknya, maka kelompok profesi itu akan tercemar di mata masyarakat. oleh karena itu, kelompok profesi harus menyelesaikannya berdasarkan kekuasaanya sendiri. ${ }^{8}$ Untuk kode etik profesi jaksa di Indonesia telah diatur dalam peraturan Jaksa Agung Republik Indonesia nomor : PERo67/A/JA/o7/2007 tentang kode etik jaksa. Dimana dalam Pasal 4, Dalam melaksanakan tugas profesi, Jaksa dilarang:

1. menggunakan jabatan dan/atau kekuasaannya untuk kepentingan pribadi dan/atau pihak lain;

2. merekayasa fakta-fakta hukum dalam penanganan perkara;

3. menggunakan kapasitas dan otoritasnya untuk melakukan penekanan secara fisik dan/atau psikis;

4. meminta dan/atau menerima hadiah dan/atau keuntungan serta melarang keluarganya meminta dan/atau menerima hadiah dan/atau keuntungan sehubungan dengan jabatannya;

5. menangani perkara yang mempunyai kepentingan pribadi atau keluarga, mempunyai hubungan pekerjaan, partai atau finansial atau mempunyai nilai ekonomis secara langsung atau tidak langsung;

6. bertindak diskriminatif dalam bentuk apapun;

7. membentuk opini publik yang dapat merugikan kepentingan penegakan hukum;

8. memberikan keterangan kepada publik kecuali terbatas pada hal-hal teknis perkara yang ditangani.

Dalam kasus Jaksa Uraini terbukti melanggar kode etik jaksa dalam pasal 1 dan 4, dimana Jaksa Uraini menerima uang dari keluarga Angling Yusuf sebesar Rp. 318 Juta dengan imbalan hukum oleh Angling dibawah 10 tahun penjara. Namun dalam pelaksannanya Angling dihukum 10 tahun penjara dan uang yang dikembalikan hanya Rp 150 Juta. Hal ini membuktikan bahwa Jaksa Uraini menerima suap serta menyalahgunakan jabatannya untuk kepentingan pribadi. Menggejalanya perbuatan professional yang mengabaikan kode etik profesi karena beberapa alasan yang paling mendasar, baik sebagai individu anggota

${ }^{8}$ Muhammad Abdulkadir, Ada beberapa pengaruh dalam kode etik profesinya,Semarang, 2007. 28 
masyarakat maupun karena hubungan kerja dalam organisasi, profesi. Menurut Abdulkadir Muhammad, terdapat beberapa alasan yang mengakibatkan profesi hukum mengabaikan kode etik porfesinya antara lain 9 :

1. Pengaruh Jabatan, Seseorang mengabaikan kode etik profesinya karena merasa dikekang jika sebagai bawahan dan dituntut untuk menghormati dan taat setiap perintah yang dilakukan oleh atasan.

2. Pengaruh Konsumerisme, Seseorang mengabaikan kode etik profesinya karena melihat peningkatan akan kebutuhan yang tidak sebanding dengan penghasilan yang diterima. Hal ini mendorong seseorang memperoleh penghasilan yang lebih besar melalui jalan pintas yaitu dengan mencari imbalan jasa dari pihak yang dilayaninya.

3. Pengaruh Lemah Iman, Seseorang mengabaikan kode etik profesinya karena tidak mempunyai benteng yang kuat akan ajaran agama. Sehingga menyebabkan tergoda dan tergiur dengan bermacam ragam bentuk materi di sekitarnya.

Dengan alasan tersebut, perlu ada suatu solusi yang dapat menyelesaikan permasalahan kode etik profesi termasuk kode etik jaksa. Solusi yang bisa ditawarkan agar menciptakan penegakan kode etik profesi hukum yang baik antara lain:

1. Terkait dengan jabatan, perlu ada sistem promosi jabatan berdasarkan merit system. artinya promosi jabatan bagi jaksa berprestasi dan rekam jejaknya baik. Bukan berdasarkan upeti yang diberikan kepada atasan atau bagian pembinaan dan kepegawaian yang sudah menjadi rahasia umum menjadi praktik yang lazim di kejaksaan.

2. Terkait dengan konsumerisme, perlu diterapkan pemberlakuan sanksi sosial pada pelanggar kode etik profesi jaksa, sehingga bisa memberikan efek jera dan mencegah calon pelaku lainnya melakukan pelanggaran. Sanksi sosial itu, misalnya, pelaku dihukum kerja sosial, membersihkan jalanan dengan memakai pakaian pelanggar kode etik profesi dan ditonton oleh khalayak ramai di jalanan.

3. Terkait dengan lemah iman, perlu diterapkan pendidikan agama yang baik. salah satu praktisnya bagi pelanggar kode etik dikirim ke pesantren bagi yang beragama islam, dan bagi yang non islam dapat dibimbing oleh pemimpin-pemimpin agama melalui asrama. Sehingga diharapkan dapat berbuat jujur dalam menjalankan profesi kerja masingmasing. ${ }^{10}$

\section{SIMPULAN}

Menjelaskan bagian pembahasan dari penulisan ini yang berjudul Kode Etik Jaksa, Pengertian Kejaksaan, Pengertian Jaksa, Pengertian Jaksa Agung, Kode etik untuk sebuah profesi adalah sumpah jabatan yang juga diucapkan oleh para pejabat Negara. Kode etik dan sumpah adalah janji yang harus dipegang teguh. Artinya, tidak ada toleransi terhadap siapa pun yang melanggarnya. Benar adanya, dibutuhkan sanksi keras terhadap pelanggar sumpah dan kode etik profesi. Bahkan, apabila memenuhi unsur adanya tindakan pidana atau perdata, selayaknya para pelanggar sumpah dan kode etik itu harus diseret ke

\footnotetext{
9 Muhammad Abdulkadir, Ibid.,hlm28

${ }^{10}$ Muhammad, Abdulkadir, 1997,Solusi Penyelesaian Masalah Etika Profesi Hukum, Bandung : PT. Citra Aditya Bakti
} 
pengadilan.Kita memang harus memiliki keberanian untuk lebih bersikap tegas terhadap penyalahgunaan profesi di bidang apa pun. Kita pun tidak boleh bersikap diskrimatif dan tebang pilih dalam menegakkan hukum di Indonesia.

\section{SARAN}

Jadilah seorang jaksa yang dapat mampu mengabdi kemasyarakat tanpa harus melakukan pelanggaran-pelanggaran yang dapat merugikan diri sendiri maupun orang lain serta bangsa dan Negara,dalam melaksanakan tuganya harus tetap patuh pada Tuhan yang maha esa serta patuh terhadap segala aturan yang berlaku,

\section{DAFTAR PUSTAKA}

Agus Santoso. 2014. Hukum, Moral, Dan Keadilan. Yang Menerbitkan Kencana Prenada Media Group: Jakarta

Harian Orbith. 2009. Pengertian Etika dalam artian Luas , Jakarta.

Liliana Tedjosaputro. 2006. dalam Supriadi tentang Etika \& Tanggung Jawab Profesi Hukum Di Indonesia, Sinar Grafika, Jakarta.

Muhammad Abdulkadir. 2007. Ada beberapa pengaruh dalam kode etik profesinya, Semarang.

Muhammad, Abdulkadir. 1997. Solusi Penyelesaian Masalah Etika Profesi Hukum, Bandung: PT. Citra Aditya Bakti

M. Yahya Harahap. 1998. Kode Etik sebagai pelaksana para profesionaletika profesi, Jakarta.

Soerjono Soekanto. 2009, Jaksa. Jaksa Agung, Jakarta.

Sukarton Marmosudjono. 1998. Melihat Nilai Etika dari segi Keluhuran Hukum, Jakarta.

\section{PERATURAN PERUNDANG-UNDANGAN:}

Undang-Undang Dasar NRI Tahun 1945

Undang-Undang Nomor 16 Tahun 2004 tentang Kejaksan Republik Indonesia

Peraturan Jaksa Agung Republik Indonesia nomor : PER-067/A/JA/o7/2007 tentang Kode Etik Jaksa 